\title{
On the Analogy Between Business and Sport: Towards an Aristotelian Response to The Market Failures Approach to Business Ethics
}

\author{
Matthew Sinnicks ${ }^{1}$ (D)
}

Received: 7 February 2020 / Accepted: 16 January 2021 / Published online: 7 February 2021

(c) The Author(s) 2021

\begin{abstract}
This paper explores the notion that business calls for an adversarial ethic, akin to that of sport. On this view, because of their competitive structure, both sport and business call for behaviours that are contrary to 'ordinary morality', and yet are ultimately justified because of the goods they facilitate. I develop three objections to this analogy. Firstly, there is an important qualitative difference between harms risked voluntarily and harms risked involuntarily. Secondly, the goods achieved by adversarial relationships in sport go beyond the function of sport, i.e. to entertain audiences. Thirdly, the most plausible account of the athlete's motivational development starts with their love of the sport, which can explain a commitment to the sporting ethics in a way that is not paralleled in business. I close by drawing attention to the ways in which an Aristotelian conception of business ethics may be able to accommodate these objections.
\end{abstract}

Keywords Ethics of competition · Market failures approach $\cdot$ Aristotelianism

\section{Introduction}

In this paper, I explore the notion that business calls for an adversarial ethic akin to that of competitive sport. This conception of business ethics was partly resuscitated by Heath (see 2014, p. 6), whose influential Market Failures Approach (MFA) to business ethics has been one of the most notable developments in the field in recent years, and has generated much commentary in the business ethics literature (see Martin 2013, Jaworski 2014, Néron 2016, Silver 2016, von Kriegstein 2016, Hsieh 2017, etc.). It seeks to outline the 'implicit morality of the market' which is to "to generate a more efficient allocation of its resources and labor time" (Heath 2014, p. 31). This efficiency is taken to be "an irreducibly normative principle" (Heath 2014, p. 10) that, in ideal circumstances, would allow market transactions to lead to Pareto optimality, i.e. a situation in which no one can be made better off without making someone else worse off. Where Pareto-inferior outcomes are realised by market transactions, this is referred to as 'market failure', and the MFA aims to provide a moral code that proscribes acting

Matthew Sinnicks

matthew.sinnicks@york.ac.uk

1 The York Management School, University of York, Freboys Lane, York YO10 5GD, UK in such a way as to promote or exploit such market failures. Indeed, according to Heath, "these 'efficiency imperatives' are pretty much all there is to business ethics, at least with respect to market transactions" (2014, p. 174). This efficiency is to be achieved through market competition, hence the attempt to draw an analogy with sporting competition.

The analogy between business and sport is supposed to suggest that, while adversarial roles do not dissolve morality, both domains call for behaviours that are contrary to 'ordinary morality' as a result of their adversarial structure, and yet this is ultimately justified by the goods they facilitate. In both cases, the good facilitated is not the aim of those engaged in the activity. Businesses aim at profit, and yet the goods of business include the efficient provision of goods and services, and a resulting contribution to social prosperity. Likewise, athletes and sports teams aim at victory, and yet the purpose of sport is to entertain audiences as a result of sporting competition, and also, as I go on to suggest below, the intrinsic enjoyment of participation and a resulting opportunity for moral education. Thus, an analogy with sport allows us to better understand the competitive ethics appropriate to business. In this paper, I develop three objections to this analogy with the aim of casting doubt on the permissibility of apparently unethical actions in business.

The first of these is the objection from voluntariness. The harms that can come our way through the adversarial 
structure of competitive sport, e.g. a hard tackle in football or a left hook in boxing, are justified by the voluntary assumption of an adversarial role. However, we can be harmed by the adversarial nature of business and the market in ways that extend well beyond our voluntary participation. Even if the value of the market is not contingent on it being voluntary, there remains an important qualitative difference between harms risked voluntarily and harms risked involuntarily, a difference that limits the effectiveness of the analogy.

The second objection focuses on the goods of sport. The goods achieved by adversarial relationships in sport go beyond the perceived social function of sport, i.e. to entertain audiences, etc. Sport provides opportunities for the achievement of human excellence in a way that is far more systematic and integral than is the case in business and the market. These goods provide a more compelling rationale for our acceptance of apparently unethical behaviour. The adversarial nature of sport and therefore the apparently unethical actions that it requires are internally related to the goods sport achieves, whereas this is not so with business.

Thirdly, the argument from motivation. The most plausible account of the athlete's motivational development starts with their love of the sport. This is required for the commitment necessary to achieve excellence, and thus is present long before competitive success is a feasible aim. It is possible that success in business is partially born of an enjoyment of competitive intensity, and indeed this is likely for the most successful business leaders and entrepreneurs, but such a commitment is not subordinate to the goods of business (e.g. the efficient allocation of goods and services) in the same way and to the same extent as is the case in sport. Furthermore, there is a related problem with the motivational force of arguments in favour of a competitive ethic in business, as it is hard to imagine why someone not committed to the precepts of ordinary morality would care about upholding the implicit norms of a competitive domain. While the market might serve the good of promoting efficiency, businesses aim at profit in ways that sometimes exploit market failure, and so it is not clear why someone unmotivated by ordinary morality would act so as to abide by the implicit norms of the market rather than the aims implicit in this particular kind of business practice.

While these arguments can stand alone as objections to the analogy, they also point us in the direction of a rival, Aristotelian, approach to business ethics. In the final section, I provide a sketch of an Aristotelian alternative to the MFA and conclude that our ordinary conception of ethics is already compatible with a strong degree of context dependency. This, I suggest, is more than enough to accommodate the apparently unethical actions sometimes required by competition, but only when motivation is in good order and focused on the goods of the activity in question.
My aim is not to argue that the market is-all things considered-bad, but rather to challenge a facet of the MFA, and secondarily to do so in a way that might make another perspective on business ethics, the Aristotelian approach, seem more palatable. This latter approach may be less enthusiastic about the market than the MFA, but for the most part Aristotelian business ethicists are not anti-market overall, just wary of its excesses.

\section{The Analogy Between Business and Sport}

One way to understand business ethics is as an ethics that pertains to a fundamentally competitive domain, as distinct from our ordinary conception of ethics which prioritises cooperation, benevolence, altruism, and so on. This view taps into important and widespread intuitions about the nature of business as being fundamentally competitive, which suggests an analogy between the ethics of business and the ethics of other competitive domains, such as sports or games. This conception finds a classic statement in Carr's (1968) famous comparison of business to poker. However, while some defenders remained (e.g. Allhoff 2003), it had largely fallen out of favour (see Koehn 1997), as research focusing on normative ethical theories, such as deontology, consequentialism, Rawlsian conceptions of justice, and virtue ethics-all of which hold that our ordinary cooperative and often altruistic ethical commitments are applicable to the domain of business - came to dominate the field of business ethics in the 1980s and 1990s.

The MFA is a reaction against a conception of normative business ethics that, critics would suggest, consists of drawing up a "wish list of things that we would like corporations to do" (Heath 2019, p. 22). This 'wish list' approach leads to business ethics being seen as insufficient for the hardnosed world of business. The MFA instead seeks to explore important theoretical and philosophical issues in business ethics without falling prey to the alleged shortcomings of research guided by the traditional menu of normative theories. While the MFA is distinct from this traditional menu, it has important similarities with McMahon's work (see McMahon 1981, 2013; as well as Moriarty 2020), and some affinity with a variety of other 'business-focused' or explicatory approaches to business ethics (e.g. Sternberg 2000; Marcoux 2009).

\section{According to Heath}

There is a close analogy... between 'corporate social responsibility' and the concept of 'good sportsmanship' in competitive team sports. In the case of sports, the goal is clearly to win - but not by any means available. Every sport has an official set of rules, which 
constrain the set of admissible strategies. Yet it will generally be impossible to exclude strategies that respect the letter of the law, while nevertheless violating its spirit (e.g. taking performance-enhancing drugs that have other legitimate uses, and therefore have not been banned). 'Good sportsmanship' consists in a willingness to refrain from exploiting these loopholes, while nevertheless retaining an adversarial orientation. In other words, the obligation is to be a team player and to compete fairly, but not necessarily to let the other side win $(2014$, p. 91$)$

This analogy has been drawn on by several other scholars. While holding that it is too narrow, Singer (2018) takes the MFA as its point of departure and draws on the analogy between business and sport. Smith (2019a, 2019b) wants to give ethical intent a more central position than Heath, but nevertheless embraces the basic tenets of the MFA and casts his own position as a "supportive clarification" (Smith 2018, p. 604) of Heath's position, and also draws on the analogy.

On this view, the ethics of business, like the ethics of sport, is constrained by a set of domain-specific rules, but is nevertheless compatible with actions contrary to ordinary morality, and thus divorced from concerns such as cooperation and altruism. In various sporting contexts, we are permitted to perform actions which harm, or have the potential to harm, our opponents. Outside of the special context of sporting competition, these actions would be unethical, and I term these kinds of action 'apparently unethical behaviour' or 'apparently unethical actions'. A hard tackle is permissible in football, a left hook is permissible in boxing, but both are apparently unethical, in the sense intended, because they would both be impermissible in the ordinary run of life. Likewise, so the argument goes, in business we may attempt to deceive others, e.g. by exaggerating the benefits of a product, or harm them in other ways, e.g. by competing with sufficient aggression that they may be driven out of business. In other circumstances, i.e. in the run of ordinary life, we tend to regard deceiving people, or threatening their ability to make a living, as being impermissible, but just as sporting competition renders tackling and punching permissible, business renders actions which can cause these harms permissible.

In both business and sport, the goods served by the activity justify this special status and render apparently unethical actions acceptable. Yet, in both cases, this good is not actually the aim of those engaged in the activity. Businesses aim at profit, and yet the goods of business include the efficient provision of goods and services; athletes and sports teams aim at victory, and yet the goods of sport include providing entertainment, amongst other things.

This analogy does not, however, generate a free pass to commit immoral actions: we are ethically required to avoid various loopholes and to refrain from violating the spirit of the rules. Applbaum (1999) has shown just how difficult it is to construct an account of adversarial professional ethics that departs from the requirements of ordinary morality. It would be wrong to conclude that such professions can "mint moral permissions to do what otherwise would be morally prohibited" (Applbaum 1999, p. 3). Thus, perhaps the best way to capture the point of the analogy is to note that the special competitive domains in question give rise to contexts in which many straight-forward, decontextualised ethical imperatives do not hold. This is a thought with which we are more familiar: do not lie, except when an axe murderer is looking for your neighbour, great aunt Maude asks if you like the jumper she gave you as a gift, or a young child asks whether Santa Claus is real. Context is important, and so it would be unfair to caricature the position as an attempt to defend obviously and flagrantly unethical behaviour. Nevertheless, in what follows, I offer three objections to the analogy between business and sport in order to cast doubt on the claim that apparently unethical behaviour in business has the same status as apparently unethical behaviour in sport, focusing on voluntariness, the goods of sport, and motivation, in turn.

\section{The Voluntariness Objection}

The harms that may come my way as a result of the adversarial structure of sport are justified by my voluntary assumption of an adversarial role. If I step through the ropes of a boxing ring, I become fair game in a way that a person walking along the street is not. By contrast, we can be harmed by the adversarial nature of the market in ways that extend well beyond our voluntary participation. This is because while market transactions themselves are typically consensual, having to participate in the broader system is not.

This point brings to mind Hume's famous rejection of social contract theories of political obligation as being akin to a suggestion that "a man, by remaining in a vessel, freely consents to the dominion of the master; though he was carried on board while asleep, and must leap into the ocean and perish, the moment he leaves her" (1994, p. 193). In such a position, it is possible to consent to particular contracts, but the wider context is a result of unchosen circumstances and is potentially or actually harmful in a variety of ways. This is no doubt true of any social formation we might be born into. However, the basic point stands, as the harms that might result from the basic structure of one's society are qualitatively distinct from harms that result from voluntary participation in an activity. The person who finds their free movement curtailed by being pinned in a wrestling match they willingly entered into is in a different position than the person who finds their free movement curtailed as a result of 
being born into an authoritarian society. Indeed, the person pinned in a wrestling match they voluntarily entered into is in a different situation from someone pinned in a wrestling match within the context of a society in which wrestling matches are the only way to make a living. Thus, the argument I develop in this section depends on the contrast between voluntary participation in sport, and the involuntary harms that could result from any set of social and economic circumstances. However, because the MFA focuses on market society, I restrict my discussion to potentially harmful aspects of this society, and in particular on its adversarial nature.

Heath acknowledges the basic problem of voluntariness that I raise here. He says, "sport is both voluntary and unserious, in a way that having to make a living in a capitalist economy is not" $(2014$, p. 9). However, he argues that it does not undermine the fact that the analogy illuminates the nature of business ethics: "This would be an issue if I thought that the voluntariness of transactions was important to the normative justification of the market (which I do not)" (ibid).

The possibility of being harmed in a way that is not implicit in one's voluntary transactions, i.e. simply by having to make one's way in a society shaped by the adversarial nature of the market, may indeed be unfortunate. However, according to the view under examination, the benefits of the market outweigh it. It would be preferable if the market could provide the benefits it does without both particular bad features of life under the market, such as people feeling compelled to accept low paid, insecure, or demeaning jobs out of necessity or fear of greater evils. It would also be preferable if one could do without the more general badness of the pressure to adopt a competitive and adversarial ethos for much of one's life. The existence of involuntarily risked harms is, at the very least, a morally unattractive feature of social and economic life, and one that invites us to focus on the goods provided by the market.

Both Cohen and Peterson (2019) and Steinberg (2017) claim that Heath's position is fundamentally consequentialist in structure. Heath disavows this: his stated aim is to provide "a more rigorous articulation of the central principles that structure the capitalist economy" (2014, p. 91) and more generally the MFA aims to ground business responsibilities in the "powerful ethical resources hiding in plain sight within the "implicit morality of the market" (Norman 2014, pp. 27-28), rather than urging corporations to promote general welfare, or some other desirable end. This implicit morality is taken to be that of Pareto-efficiency, a situation in which it is impossible to reallocate resources to make one person better off without making someone else worse off.

However, reconstructing norms in the way the MFA aims to is only worthwhile if it at least coheres with a valuable practice, and thus is capable of being cast in the form of a 'wish list'. A rational reconstruction of the norms implicit in an assassin's practice might be interesting from the perspective of philosophical anthropology, but we would want and expect it to be normatively inert. Only when an activity has clear connection to the common good will be an explicatory approach to the ethics of that activity be apt. Explicating the norms of the market may require no further rationale for those already committed to the market, but Heath clearly intends his account to be persuasive to those who are tempted by other theories, or at the very least to generate compelling ethical guidance, in the form of a variety of principles (see Heath 2014, p. 37), to those not already committed to upholding the implicit morality of the market.

If this is so, then this feature of the MFA must take a consequentialist form. An argument may have consequentialist elements without thereby rendering the whole argument consequentialist, and without invoking the features of consequentialism that make many way of the term. The consequentialist element is especially pronounced given that efficiency is the implicit morality of the market. While Pareto-efficiency is not reducible to utility-maximisation, it remains an inherently consequence-focused concept. Indeed, Heath speaks of the compensating benefits of the market. He claims that the "well-structured, competitive market economy produces not just utilitarian gains (where some might benefit while others lose) but Pareto improvements (where everyone benefits)" (2014, p. 197).

The adversarial ethic that the analogy with sport illustrates is supposed to be a set of 'deontic constraints', albeit with "deontic weakening with respect to everyday morality" (Heath 2014, p. 9 [emphasis in original]). However, society as a whole is not necessarily duty bound to abide by the free market, and so when making a case in favour of our tolerating a system which requires an awful lot of apparently unethical behaviour, part of the rationale for this toleration is surely that the benefits of doing so outweigh the costs. I see no way of making sense of this that is not broadly consequentialist.

The point here is not that the market does not serve any good. Nor is it even that the market does not serve a good that outweighs the badness of involuntary adversarial relationships, even if allowing an adversarial institution to so fully structure all of our lives seems particularly likely to undermine our chances of living well. After all, we spend half of our waking lives at work, and a good portion of the other half preparing for or recovering from it. Rather, the point is that the harm that results from an involuntary adversarial relationship is qualitatively different from the harms that arise from voluntary participation in sport, and further that this qualitative difference ought to make us less tolerant of the involuntary harms that spring from having to make our way in capitalist society. 
Imagine a situation in which some small amount of enforced, potentially lethal, gladiatorial combat were necessary to achieve some important good, for instance, to appease the gods. In such a scenario, many people would likely draw the conclusion that the good served, i.e. avoiding the wrath of the gods, is so good that it makes it worth tolerating this harm. This is a perfectly reasonable position to hold. However, we would still regard this situation as being quite different from, and far more morally grave than, a situation in which purely voluntary competition could achieve the same good. Under circumstances in which gladiatorial combat were necessary for societal prosperity, to use the example of the good the MFA attributes to business and the market, I suspect we would draw up more stringent ethical guidelines, for both participants and spectators, than are currently in operation for mainstream sports. While it may not be possible for participants to engage in such combat half-heartedly, and so they could not be expected to compete with benevolence and altruism clearly in mind, I suspect we would frown on displays of bravado, forbid television coverage, and so on. A necessary evil remains an evil.

Consider instead a more realistic analogy. Airport security guards are empowered to occasionally use some degree of force against those suspected of wrongdoing, even though this means that in some tiny number of cases innocent people may be tackled to the ground by those security guards. We can recognise that this harm is qualitatively different from the harm of being tackled to the ground in football or rugby, even if we agree that the good achieved by permitting security staff to use force is, all things considered, justified. Indeed, in business, just as with this airport security example, we have an all things considered case in favour of apparently unethical behaviour, but in sport this is not so: the goods of sport are inconceivable without the adversarial element, a thought to which I return below. Thus, there is an important disanalogy between business and sport. The harms that arise through sport are almost always voluntarily risked, whereas having to make a living in capitalist society exposes us to involuntarily risked harms that result from the adversarial structure of the competitive market. More broadly, this observation gestures towards the suspicion that harms are too wantonly and unevenly distributed under capitalism, which is compatible with the Pareto-efficiency the MFA claims as capitalism's central good.

This suspicion underpins a reason for being sceptical about the broader, macro-level consequentialist arguments in favour of it, or an ethics that draws significantly on functional roles within the capitalist system. Likewise, due to voluntary assumption of adversarial roles, harms risked in sport are not wantonly distributed. In sport there are also mechanisms to ensure that they are not too unevenly distributed. There are leagues, ranking point systems, matchmakers, etc. who are able to ensure some parity of competitiveness, and again, voluntariness allows a competitor to back out if the risk of harm is too great. If the average person who decided to take up boxing were forced to compete against seasoned professionals from the outset, then the harms they endured as a result would have a different ethical flavour to the harms faced by boxers who do, in fact, meet in the ring. "All the world's a stage" wrote Shakespeare, but-to turn our analogy against itself-if all the world were a boxing ring, we would expect social life to be unpleasant. Having to protect ourselves at all times is quite a burden.

\section{The Goods of Sport}

Given that market transactions themselves are typically voluntary, and given that any social and economic system we find ourselves in necessarily precedes any opportunity we could have to consent to it, it may be thought that the issue of involuntariness is not especially pressing. Thus, the arguments addressed in this section, from the goods of sport, and the following section on motivation may be thought to carry more weight. In any case, we should not lose sight of the fact that voluntariness is no guarantee of rightness. If someone volunteered to be cannibalised, have a healthy limb amputated, or even just to be publicly humiliated, we may still regard those who assist in the fulfilment of such desires - the cannibal, the amputator, and the humiliator - as being ethically dubious. The reason for this is that we are often interested in the goods served by a particular activity or action, and an understanding of the goods of various sporting competitions reveals another disanalogy between sport and business. It also helps to explain why such sporting competitions find a wider and more devoted audience than do other competitive domains.

According to Heath, it is important to recognise that the good of individual competitors diverges from the good of the sport, otherwise "there would be no need to test for performance enhancing drugs" (2014, p.98). The analogy between business and sport thus assumes that the good of teams and athletes is victory achieved through competition, and the good for spectators is, principally, the entertainment provided by the competition. Singer (2018) adds to this the socialising and educational role of sport, which is contrasted with its competitive nature. What seems to be missing, on this formulation, is an appreciation of the distinctive goods of sport, and the human excellence achieved by the athletes. These goods are what make risking harm worthwhile, especially when, at the outset of any athlete's engagement in sport, there can be no expectation of significant income as a result, a point I return to in the following section.

Thus, Singer's point about education is quite right, but it only begins to adequately capture the goods of sport if we have an expansive understanding of the education sport can 
provide. Restricted to a basic developmental contribution to educating children, it ignores much of what is valuable about sport. Indeed, sport has the capacity to play a continuing role in the moral education of us all. Camus once claimed that he learned all he knew about morality and obligations from football, but even if most of us want to credit other sources with some of our moral development, the ethical significance of sporting participation remains impressive, and can contribute to our understanding of fellowship and teamwork, and to our development of perseverance, patience, courage, and much else besides.

There is also an important aesthetic dimension which makes sporting competition, in many cases, especially compelling. CLR James likened cricket to an artform (1963), and David Foster Wallace (2006) went even further when characterising watching Roger Federer play tennis as a kind of religious experience. Mumford recommends that we bring "the aesthetics of art and sport... closer together" (2012, p. 7) and notes that it is possible to appreciate sport for intellectual reasons, a preference manifested in the watching habits of so-called purists rather than partisans, though it is probably common to combine both orientations.

Therefore, the central distinction revealed by this discussion is that the market is valuable for its function, whereas sport is inherently worthwhile. If there were some way to have the central goods of the market without the competitive and adversarial domain of business, then we would probably be inclined to do so. This is the impulse behind attempts to simulate the market (see Cockshott and Cottrell 1993), or to devise forms of 'market socialism' (see Ollman 1998; Nove 2003) which might allow us to retain the informational benefits of the price system, that played such a role in the socialist calculation debate, while mitigating the broader effects of market conditions as they exist under capitalism. For sport, the matter is quite different. This is both because the goods of sport are not separable from sporting competition, and because we regard the goods of sport to be intrinsically, rather than instrumentally, valuable. Hence, amateur participation is widespread, and even sports fans can be morally educated as they develop a subtler appreciation of tactics and techniques (Sinnicks 2019).

Again, we see a qualitative difference between the harms generated by the adversarial structure of sport and the harms generated by the adversarial structure of the market. Apparently unethical behaviour in sport, i.e. behaviour acceptable within sporting competition which would be unethical if carried out in the ordinary run of life, is necessary to the achievement of various kinds of excellence, to the aesthetic beauty achieved, and to the moral education provided by sport. As such, hard challenges, attempts to intimidate opponents, etc. are inseparable from the goods of sport, and thus it is difficult to coherently regret their existence. The harms generated by the adversarial relationships required by the market, on the other hand, are simply regrettable, even if we judge them to be ultimately acceptable because of the goods they facilitate. Likewise, if it were shown that prisons were necessary for the maintenance of social order-against much available evidence, it has to be said (see Mathiesen 2005) we might still lament this fact rather than celebrating it, even if our commitment to social order were unwavering.

This issue reveals a deeper disagreement about the nature of ethics, namely the way in which the MFA emphasises the social function of morality over substantive ethical content. Heath claims that the purpose of morality is to reduce collective action problems (2014, p. 102), and that capitalism is unworkable without business ethics $(2014$, p. 265). While the MFA is perfectly able to acknowledge the benefits of cooperation, there is a danger that this conception of ethics will unduly neglect the question of what is good and worthwhile. Our reflections on what is good and worthwhile may, of course, have the function of reducing collective action problems, but presumably such an outcome is desirable because the actions aimed at are good and worthwhile. Where the goods aimed at are illusory, there may be 'felt' collective action problems that are better left unresolved. For instance, imagine a group of chess enthusiasts who set out to eat nothing but junk food in a bid to hold a record as the world's fattest chess club, in order to enjoy the fame, glory, or sense of satisfaction that holding such a record might provide. However, in this scenario each individual is wary of the harms of obesity, and so wants the others to put on most of the weight, and as a result maintains a balanced diet and solid exercise regimen. Here we have a collective action problem, but in this case a resolution is undesirable because the goal it frustrates is not worthwhile.

Given that the appeal of the MFA hinges on the value of the function of the market, it presupposes a division of moral labour, according to which moral goods are pursued by institutions rather than individuals. This moral division of labour seems to be justified because it tends to promote human welfare overall. However, it often requires individual human beings to develop interests, desires, and characteristics that prevent them from flourishing, e.g. where excessively adversarial and competitive traits are conducive to success. In the case of legal institutions, this division of moral labour may be a price worth paying, but it is less clear that this is so in the case of business organisations. This is in part because we imagine that the good of justice requires legal institutions, whereas the relationship between social prosperity and the market is more contingent, and it is an open question as to whether social prosperity could be achieved without the market. Similarly, while we would not trade our current situation for one where justice were less available but legal institutions were less adversarial, it is possible, likely even, that we would be willing to sacrifice some financial prosperity for a world less in thrall to the market. 
It would probably be an exaggeration to claim that the flourishing of each is a condition of the flourishing of all: those who sacrifice themselves in a glorious revolution do not thereby doom the revolution to failure. Nevertheless, there is something disquieting about a position which is untroubled by the prospect of some people being lumbered with a treadmill of a job, morally impoverished because of an excessively combative work environment or job role, or simply wasting their time and efforts on trivialities, because it contributes to an overarching social function. Critiques of work in market-based societies usually focus on low paid and insecure work, as well they might, but it is also worth remembering former Facebook employee Jeff Hammerbacher's comment that the "best minds" of his generation "are thinking about how to make people click ads" (Vance 2011). This work may contribute to the market overall, and the market may contribute to societal prosperity overall, but there is something undeniably sad about this deployment of talent.

\section{The Argument from Motivation}

Because of the goods of sport, and because making a living from sport is an extremely unlikely eventuality even for highly talented young athletes, and certainly for the overwhelming majority of people who participate in sport, it is safe to assume that even for elite level professionals, an engagement in a particular sport is initially motivated by a love of that sport. This is probably not true for business and the market. However, it would be a caricature to present business and the market as domains in which actors are always and only extrinsically motivated. While, as Heath notes, "making peace with capitalism essentially involves acknowledging the value of the profit motive" (2014, p. 11 ), there is clearly scope for an enjoyment of competitive engagement in business life, and indeed it is hard to make sense of the extreme levels of commitment and passion shown by well-known business magnates such as Steve Jobs or Jeff Bezos solely in terms of instrumental motivation. Nevertheless, it seems fair to assume that extrinsic motivation is considerably more likely in the domains of business and the market. While ordinary workers may be partly motivated by a sense of fellowship or friendship in the workplace, the tasks carried out in most ordinary jobs do not attract many amateur participants. Thus, motivation presents a third significant disanalogy between business and sport.

Our expectations about motivation in sport colour our judgements as spectators as well as participants. Sports fans typically express frustration when they perceive a particular athlete as 'only in it for the money', just as we would disapprove of the airport security guard who tackled people to the ground with relish. An athlete insufficiently concerned with glory and the achievement of sporting excellence may still permissibly engage in apparently unethical behaviour, but our general attitude towards such behaviour is shaped by our understanding that sport is a domain in which such motivations are sometimes, perhaps often, laudable. As such, this permissibility is akin to that of using one's right to free speech to spout ignorant and deliberately offensive nonsense: permissible in that it cannot be legitimately proscribed, but still something we should take a dim view of. Even where an individual's love of their sport has declined, eroded through years of striving for professional success, the nature of victory celebrations is often hard to make sense of unless some of that love survives. Therefore, the apparently unethical actions required for sporting success-competing in a way that risks harming, and in some cases seriously injuring, the opposition - are, in part at least, motivated by a commitment to the goods of sport and the achievement of excellence. This motivation by the goods of sport also feeds into a broader ethical motivation that allows us to see how the apparently unethical behaviour permitted in sport is actually compatible with, rather than in contrast to, our ordinary ethical concerns.

The ethics of sport may have been degraded by professionalisation (see Whysall 2014), and it would be wrong to paint too rosy a picture. Indeed, this phenomenon of degradation supports my broader argument, as it suggests that there was something inherently worthwhile in sporting competition that was liable to degradation. As a result of this, there remain a number of ways in which the ethics of sport seems to transcend the ethics of adversarial competition. For example, players of various sports sometimes ease off an outclassed opponent rather than run up the score, cricketers sometimes 'walk' (i.e. depart the field of play because they know themselves to be out, even when an umpire has not given them out), and so on. Such behaviours are supererogatory, from the perspective of the basic requirements of sportsmanship and the minimal standards required to maintain the existence or popularity of the sport. Indeed, such behaviours seem to make sense only if competitors genuinely care about the sport in question or are guided by the precepts of ordinary morality. Intrinsic motivation tends to mitigate possible excesses of adversarialism, and it is because of their intrinsic motivation that many sporting competitors behave as they do.

The analogy between business and sport presupposes that in such competitive domains, the requirements of ordinary morality, often associated with the 'golden rule' of treating others as we would wish to be treated, are suspended. However, this holds more for business than it does for sport, revealing another notable disanalogy. Intuitively, it seems implausible to think, when playing sport, that we would wonder 'how would I feel if the opposition did this to me?' (Heath 2014, p. 102). However, in an interesting way, we do. It is a feature of voluntary participation that we know, and 
endorse, the fact that our opponents are trying to beat us. If a team wins a tournament because their opponent 'throws', i.e. deliberately loses, the final, they would be disappointed. If someone wins a tennis tournament because all of their opponents withdraw with injuries just before each match, they would be unlikely to celebrate such a triumph with the usual vigour. It is hard to imagine Pepsi being similarly saddened if Coke exited the market.

In sport, we want our opponents to compete against us. As Nguyen puts it "often, I must try quite hard to beat my opponent for them to have a good time" (2017, p. 123). Such desires are not universal, and one demonstration of the fact that some athletes are not concerned with fair and honest competition, and do not wish to be treated as they treat others, is the phenomenon of serious and systematic rule breaking, a phenomenon also familiar to the world of business.

According to the MFA, competition in business "can provide at best an excuse for unethical conduct, not a justification" (Heath 2018, p. 533). However, "the availability of the excuse may be conditional upon the firm having taken reasonable measures to bring other firms into compliance" (ibid), that is to say, compliance with various regulations, and indeed the broader ethical commitments implicit in the market that such regulations, when in good order, seek to uphold. If everyone is doing it, then the benefits of doing it become negated, and the harm that results from not doing it becomes hard to ignore. Thus, non-compliance "is like doping in sport, where the primary effects cancel out" (Heath 2018, p. 532). While sporting competition necessitates many apparently unethical actions, i.e. the hard tackles and lefthooks which would be unethical outside of sporting contexts, use of performance-enhancing drugs (PEDs) remains morally censured, though it can be forgiven when athletes have the right intentions (when, for instance, there are therapeutic use exemptions - see Pike 2018). Again, we see that the motivation of athletes, and our expectation that they be somewhat intrinsically motivated, colours our ethical judgments of them. This intrinsic motivation itself grounds a commitment to the ethics of sport understood in a broad sense, and not merely a sense of upholding the implicit norms of competition.

What, then, is the status of the claim that use of PEDs is unethical? It is hard to imagine someone being totally unpersuaded by the ordinary ethical objections to PED use, but persuaded by an objection based on the fact that it undermines the norms of the practice. The practice is only valuable if it is valuable according to some practice-transcendent perspective. As a result, we may wonder why we would expect athletes to care about norms that sustain their practices, but not norms that sustain social life more generally. If we can persuade someone to forego cheating, even where doing so is likely to help them win, and even where they are unlikely to be caught, then it seems they already regard the good of victory as being subordinate to some of the precepts of ordinary morality. If someone is immune to appeals to the latter, then they are likely to be immune to appeals to the former too. To care about the implicit norms of the practice is already to be open to ethical persuasion. Indeed, if sport is able to morally educate us it is because we can draw on its lessons in extra-sporting contexts.

Those who participate are motivated by victory, but have to respect the rules so that the sport does not lose its appeal which results from the fact that it is entertaining to audiences. To undermine this appeal could undermine the weight of the aimed at victory, and perhaps even the viability of the sport itself if we take the example to extremes. However, it would really take an unimaginable, systematic breach of the rules or the spirit of the rules, to undermine the popularity of a particular sport, and it would take something truly seismic to render unavailable the good of victory. Thus, it seems implausible that sustaining the activity by abiding by its implicit norms, and thus guarding against the prospect of victory becoming unavailable, is what motivates participants to refrain from breaching rules when they can do so without consequence, or from competing in an unappealingly underhand, though legal, manner. Participants do not want to lose their source of income, of course, but they do not seem to be consumed by a burning desire to grow the appeal of their sports (i.e. in cases where sports have regional rather than global appeal, such as cricket and baseball). So again, it seems that a desire to uphold implicit norms because they are essential to the maintenance or promotion of the activity seems an insufficient basis for a normative argument. The implicit norms themselves must be deemed valuable, a notion which applies to both the motivation to compete and the motivation to abide by ethical principles.

What is the upshot of this point for the case of business and the market? Imagine someone who cares primarily about enriching themselves through exploiting market failure, which is how Heath characterises some leading work in strategy (e.g. Porter 2011). There seems to be no reason to think that we can persuade this person to care about the implicit norms of the market, but not about basic moral principles. After all, both can sometimes undermine competitive success. To persuade them of either would be a struggle as they constitute an apparently alien orientation, but to aim to persuade them to be motivated by the implicit morality of the market but not ordinary morality would be to stop at an arbitrary and excessively modest point. Even if businesses rely on a well-functioning market, it is not clear why, absent some business-transcendent moral concerns, they would be motivated to care about upholding Paretoefficiency when they can easily get away with not doing so. This is true even where it is recognised that it is best for all if Pareto-efficiency is held up as an ideal, and even where the managers, directors, and employers of the business in 
question want the market, in general, to be regulated so as to promote this end. Indeed, there is an unresolved question of why someone engaged in business practice should be motivated to uphold the norms implicit in the market, rather than the norms implicit in their industry, organisation, or workplace. If accepting the value of the market is a judgement that transcends engagement in market activities, then it seems to rely on ordinary morality. However, if we need to introduce ordinary morality as a justification at this stage, there seems to be no reason it cannot play a continuing role in reflections on ethics and business. Because of this problem with ethical motivation, it seems that the MFA is in danger of being another practically inert wish list, albeit one that settles for some very modest wishes.

\section{Towards an Aristotelian Alternative}

To cast doubt on the analogy between business and sport would be to deprive the MFA of some of its intuitive appeal. The failure of the analogy suggests that even within a paradigmatically competitive domain, such as sport, where many apparently unethical actions are permitted, we are still very much guided by extra-competitive ethical principles, i.e. principles which derive from ordinary morality. It is only in the special cases where harm is voluntarily risked, and where some important good is achieved, that apparently unethical behaviour is permitted in sport, and even then, competitors may be criticised if they are perceived to be improperly motivated. The ethics of sport as we understand it ultimately transcends, rather than exists as merely implicit in, the adversarial and competitive aspect of sport.

Having set out my objections to the analogy between business and sport in the previous sections, in this section I turn to the question of what sort of account might be able to accommodate them. While these objections are intended to be able to stand alone as reasons to be suspicious of the role the business-sport analogy plays in defences of explicatory approaches to business ethics, including the MFA which I have focused on in this paper, they also have a distinctly Aristotelian tenor. While it is impossible to do justice to the complexities of Aristotelian ethics in a single paper, let alone a single section, in what follows I attempt to outline how the points raised fit within the Aristotelian framework, with the aim of encouraging dialogue between adherents of the MFA and Aristotelian accounts of business ethics.

Developed most notably in his Nicomachean Ethics (NE) and Politics (Pol), Aristotle sets out an account of ethics that reserves a foundational place for human flourishing. The achievement of the human good is, on this view, the central aim of the ethical life. This good cannot be achieved merely through following ethical rules (NE 1094b), but requires us to develop certain excellences, i.e. virtues, of character.
After all, no one can tackle life's challenges without courage or kindness, and no life is happy in the absence of friendships, which require honesty, constancy, as well as a variety of other virtues. These virtues are, according to Aristotle, always means between opposing extremes of excess and deficiency-courage is the mean between cowardice and rashness, generosity is a mean between miserliness and extravagance, wittiness is a mean between boorishness and buffoonery-and require practical habituation to fully develop. Ultimately, human flourishing can only be achieved within a political community, a kind of association to which we are naturally suited (Pol 1252b). In what follows, I detail how the concepts underpinning the objections to the analogy between business and sport I raised above-from voluntariness, goods, and motivation-fit within the Aristotelian approach to ethics.

While the voluntariness objection is the most general of the arguments I developed above, and it seems likely that any normative theory will want to accept an important distinction between harms risked voluntarily and harms risked involuntarily, it nevertheless connects to some Aristotelian themes. Aristotelian ethics is typically concerned with questions of what virtuous individuals are disposed to do, and competing with the possibility of harming voluntary opponents seems to be more compatible with individual virtue than does possibly harming those who are not willing adversaries. Furthermore, according to Aristotle, we only deserve praise or blame for voluntary actions. Actions that are forced or a result of ignorance are to be regarded as involuntary (NE 1109b). Similarly, while actions performed under necessity or because of a fear of greater evils-which is how I characterised some of the less desirable elements of market society above-are not straightforwardly involuntary, Aristotle suggests that they are 'mixed' (NE 1110a). This point suggests there are grounds for an Aristotelian critique of harms, and indeed rewards, that result from involuntary participation, and certainly accords with the distinction between sport and business drawn in the above discussion.

More broadly, the notion that the political community is concerned to promote citizens' flourishing suggests that providing protection against involuntarily risked harms is, insofar as it is possible, a worthy goal. Similarly, we might reasonably suspect that a system in which people are forced into competitive and adversarial relationships is inimical to a sense of community, and thus the Aristotelian position is well placed to account for why we might take a dim view of some of the consequences of the adversarial nature of the market system.

The importance of voluntariness is shown by other aspects of the ethics of sport too. Sport can allow us to develop friendships (see Jones 2001), but for Aristotle friendship requires shared commitment to the good, and can only be a part of sport as a result of voluntary participation. 
Likewise, courage can be developed in sport (see Corlett 1996), but courage implies a willingness to face danger, and so again implies voluntariness. In these cases, the nature of the various goods pursued is what is most important, and so they lead us on to the argument from the goods of sport.

According to Aristotle, "[e]very craft and every method of inquiry and likewise every action and deliberate choice seems to seek some good" (NE 1094a). Thus, a focus on the good and various goods is at the heart of the Aristotelian conception of ethics. Aristotle's own writings on ethics offer a systematic examination of the goods of happiness, virtue, pleasure, friendship, etc. Furthermore, the focus on the goods of sport fits neatly with Aristotle's distinction between praxis, intrinsically valuable activity, and poiesis, instrumentally valuable productive activity. Characteristically and for the most part, sport answers to the former description, business to the latter.

Sports also fit neatly within MacIntyre's (2007) Aristotelian concept of 'practices', in some ways an extension and attempted refinement of the concept of praxis, which has been highly influential within the business ethics literature (see Ferrero and Sison 2014). Practices, in this sense, are activities that possess 'internal goods', i.e. goods which cannot be achieved in any way other than engaging in the activity in question (MacIntyre 2007, p. 187). Such goods stand in contrast to external goods, such as money, power, and fame, which can be achieved in a variety of ways (MacIntyre 2007 , p. 188), and thus have no special connection to any particular activity. These internal goods mean that practices are able to be schools of the virtues, and allow sporting practices to help us to achieve human excellence by developing such virtues as perseverance, patience, and courage.

The concept of a practice also provides a powerful account of what work could be like at its best. While it is not possible to conceive of business itself as a practice (see Beadle 2008), many forms of work available under contemporary capitalism do deserve such a status, and various sports are often taken as paradigmatic examples. The concept of a practice binds the arguments from goods, the argument from motivation, and by extension the argument from voluntariness, together, as it is the goods of an activity that motivate us to engage in it, and thus make us voluntary participants. As such, it allows us to recognise the coherence of the three objections raised in the preceding sections.

The notion that the goodness of an activity is what ought to motivate us to engage in it is central to the Aristotelian conception of proper activity, and explains why the topic of good and meaningful work-work that is not trivial or characterised by an excessive combativeness-is central to the Aristotelian approach to business ethics (see, for example, Beadle and Knight 2012; Sison and Fontrodona 2012). By contrast, an agent's reflections on the worth and meaning of their work is a difficult issue for the MFA as it is not clear that an account of ethics so focused on the broader function of an activity can account for individual motivations. This emphasis on proper motivation also allows us to clearly understand why an excessive focus on victory or prize money is troubling in the context of sport, which, as I noted in the discussion of the objection from motivation, can be frustrating even to partisan fans.

The emphasis on proper motivation also enables us to see how the goods internal to sport can prevent the pursuit of money and victory from always becoming overwhelming, and it is worth noting that Aristotelian accounts often recommend being wary of an excessive focus on money in business too, as noted by Bragues (2006). A similar point could be made about a variety of other virtues, perhaps including prudence and magnanimity, which pertain to good judgement and appropriate concern with honours, respectively, and in a sporting context and depend on agents being properly attuned to the relevant goods. Bragues also draws attention to the way the virtue of self-restraint is necessary to health and fitness (2006, p. 347) and thus is obviously important for the achievement of sporting goods. Likewise, the virtue of justice plays an important role in sport. According to Aristotle's conception of general, rather than particular, justice, the just person aims to contribute to the good of the community (NE 1129b). As Austin puts it, "This form of justice is relevant to sport in many ways. It can be developed as a player befriends teammates and seeks their good. It is also present when an athlete treats opponents, coaches, officials, and fans with respect" (2013, p. 45). Similarly, particular justice is central to sport: we want accolades for excellence to be distributed to those who deserve them, and rectificatory justice to apply to those who break rules.

So far, my account has focused on individual motivation, but given Aristotle's emphasis on politics as the summation of ethics (NE 1099b), we should not draw too sharp a distinction between individual and wider community. The interrelatedness of these levels is central to Aristotelian conceptions of ethics, including business ethics, and many Aristotelian business ethicists make a concern with the organisation central to their work (e.g. Solomon 2004, Moore 2017). According to Solomon, "[c]orporations are real communities, neither ideal nor idealized, and therefore the perfect place to start understanding the nature of the virtues" (Solomon 1992, p. 325). While Solomon's optimism about the availability of community within corporations may be unsustainable (Sinnicks 2020), there is an important grain of truth here: the sense of fellowship available within the workplace is an important part of many people's motivations at work, and thus an important and ethically salient factor in the choices they make as part of their professional lives. Another Aristotelian business ethicist, Hartman, poses the following rhetorical question: 
Do you want to be the sort of person who can enjoy only overwhelming financial success? Or the sort of person who enjoys a life in which work plays an important but not dominant role and in which that work offers challenge, variety, growth, association with interesting people, and compensation that lets you live comfortably? (Hartman 2013, p. 78)

The challenge, variety, growth, and association appealed to here are not ethically neutral and are, for the Aristotelian, legitimate, indeed unavoidable, considerations for anyone, including those in business. This thought connects to the broader concerns about moral motivation raised above. The Aristotelian approach to business ethics sees our pursuit of flourishing, and relatedly of virtue acquisition, as central to our motivation in both our personal and professional lives. Being a good friend to a co-worker may sometimes be in tension with discharging one's work duties and thereby contributing to the efficiency of the market, and for the Aristotelian it is sometimes right to prioritise the former.

Defenders of the MFA might suggest that this Aristotelian account is all well and good for the level of the individual or of the local community within a particular workplace or department — of course individuals themselves will worry about the quality of their work, how they can pursue a flourishing life, how they can act with integrity in the workplace, and so on-but the MFA focuses primarily on the macro-level of government and regulation. However, there is clearly scope for the Aristotelian approach to depart from the micro-level of individual agents. Indeed, there have been contributions by Aristotelian business ethicists on meso- and macro-level topics such as corporate governance (Sison 2008, Moore 2012), interorganizational networks (Bernacchio 2018), stakeholder theory (Wijnberg 2000), corporate philanthropy (Nicholson et al. 2020), employee rights (Bernacchio 2020), regulation (Sinnicks 2014), financial reform (Nielsen 2010), and organizations and society (Morrell 2012), amongst others. However, on the Aristotelian view, reflections on these topics aim at more than upholding the implicit morality of the market, which it regards as excessively thin. They aim to explore, and provide intellectual support for, ways in which commercial life can sustain and promote various goods beyond those spontaneously generated by the market. As such, its advocates are unlikely to be neutral between the promotion of sporting excellence and the promotion of devising ways to make people click on ads, to return to an earlier example.

To promote one form of work over another is to depart from the judgemental egalitarianism of the market. Many of our institutions are shaped by the thought that it is better to want some things rather than others, and this already has an impact on market behaviour, i.e. on what we buy, the jobs we prefer, and so on. Thus, it seems an unwelcome and ad hoc restriction to require that discussion of the broad array of topics that falls under the heading 'business ethics', and legitimate ethical guidance to people who engage in business, be subordinated to the implicit norms of the market. Indeed, if, as MacIntyre claims, avarice is a "highly valued character trait", even "a duty" (2016, p. 127) in contemporary capitalist society, and the modern economic order "provides systematic incentives to develop a type of character that has a propensity to injustice" (1995, p. xiv) - in line with the excessively competitive and adversarial ethos noted above, and connected to the Aristotelian vice of vanity - then this subordination should be resisted.

A further reason for resisting this subordination is the fact that underpinning much of our ordinary understanding of ethics, which the MFA holds is inadequate as a basis for business ethics, and our understanding of the ethics of an adversarial and competitive domain such as sport, is a conception of human flourishing. At first sight it can seem that these operate quite differently, with ordinary morality being relatively unmediated and competitive ethics being mediated by the requirements of adversarial roles. But this distinction depends on an excessively narrow interpretation of ordinary morality. Our ordinary ethical practice is always strongly mediated by the contexts we inhabit and roles we occupy, and thus already compatible with uncooperatively withholding goods from those who have no legitimate claim to them. Should I help someone who asks me for assistance in writing a paper? Yes, if that person is a friend and regular collaborator; up to a certain point, if that person is my student; no, if that person sends an unsolicited email on behalf of a dubious looking publisher. This question, and the set of answers I have offered, parallels the question of whether I should tackle someone to the ground: Yes, if that person is an opponent in a fair and appropriately matched game of rugby; maybe, if I am an airport security guard and I am beginning to suspect doing so is the only way to prevent severe harm to others; no, if that person is a random passer-by. The insight of the Aristotelian doctrine of the mean is that it encourages us to always consider such practical and contextual factors in order to avoid the extremes of excess and deficiency, which will at times require acting in accordance with the implicit norms of the market and at times to deviate from them. Because of its focus on the structure of competition and business roles that competition generates, rather than the human agents who occupy those roles, the MFA instead counsels deficiency.

\section{Conclusion}

In this paper, I have attempted to cast doubt on the analogy between business and sport, and in so doing, to undermine an important argumentative resource of the MFA, namely an intuitively appealing way of defending apparently unethical behaviour within a competitive domain. To do so, I have 
offered three arguments against the analogy: the argument from voluntariness, the argument from the goods of sport, and the argument from motivation. I intend these objections to be capable of standing alone, and thus available to those who reject the Aristotelian approach to business ethics I favour. Nevertheless, I believe the objections have a distinctly Aristotelian flavour: the virtuous person cares about whether those they harm have voluntarily consented to engage in adversarial competition, the Aristotelian perspective is well placed to focus on the distinctive goods of an activity, and its emphasis on human flourishing allows the Aristotelian perspective to make sense the ways in which we might be motivated by those goods as well as by the precepts of ordinary morality even within competition.

Acknowledgements I would like to thank Holly Smith, Craig Reeves, Jaakko Nevasto, handling editor Alejo José G. Sison, and two anonymous reviewers for JBE for comments on earlier versions of this paper.

\section{Compliance with Ethical Standards}

Conflict of interest The author declares that he has no conflict of interest.

Research Involving Human Participants and/or Animals This article does not contain any studies with human participants or animals performed by any of the authors.

Open Access This article is licensed under a Creative Commons Attribution 4.0 International License, which permits use, sharing, adaptation, distribution and reproduction in any medium or format, as long as you give appropriate credit to the original author(s) and the source, provide a link to the Creative Commons licence, and indicate if changes were made. The images or other third party material in this article are included in the article's Creative Commons licence, unless indicated otherwise in a credit line to the material. If material is not included in the article's Creative Commons licence and your intended use is not permitted by statutory regulation or exceeds the permitted use, you will need to obtain permission directly from the copyright holder. To view a copy of this licence, visit http://creativecommons.org/licenses/by/4.0/.

\section{References}

Allhoff, F. (2003). Business bluffing reconsidered. Journal of Business Ethics, 45(4), 283-289.

Applbaum, A. I. (1999). Ethics for adversaries: The morality of roles in public and professional life. Princeton, NJ: Princeton University Press.

Aristotle. (2014). Nicomachean Ethics (trans. C.D.C. Reeve). Hackett, Indianapolis, IN

Aristotle. (2017). Politics (trans. C.D.C. Reeve). Hackett, Indianapolis, IN.

Austin, M. W. (2013). Sport as a moral practice: An Aristotelian approach. In M. W. Austin (Ed.), Virtues in Action: New essays in applied virtue ethics (pp. 39-52). London: Palgrave Macmillan.

Beadle, R. (2008). Why business cannot be a practice. Analyse \& Kritik, 30(1), 229-241.
Beadle, R., \& Knight, K. (2012). Virtue and meaningful work. Business Ethics Quarterly, 22(2), 433-450.

Bernacchio, C. (2018). Networks of giving and receiving in an organizational context: Dependent rational animals and MacIntyrean Business Ethics. Business Ethics Quarterly, 28(4), 377-400.

Bernacchio, C. (2020). Virtue beyond contract: A MacIntyrean approach to employee rights. Journal of Business Ethics. https:// doi.org/10.1007/s10551-020-04435-2.

Bragues, G. (2006). Seek the good life, not money: The Aristotelian approach to business ethics. Journal of Business Ethics, 67(4), 341-357.

Carr, A. (1968). Is business bluffing ethical? (pp. 143-155). JanuaryFebruary: Harvard Business Review.

Cockshott, W. P., \& Cottrell, A. (1993). Towards a new socialism. Nottingham: Spokesman Books.

Cohen, M. A., \& Peterson, D. (2019). The implicit morality of the market and Joseph heath's market failures approach to business ethics. Journal of Business Ethics, 159(1), 75-88.

Ferrero, I., \& Sison, A. J. G. (2014). A quantitative analysis of authors, schools and themes in virtue ethics articles in business ethics and management journals (1980-2011). Business Ethics: A European Review, 23(4), 375-400.

Foster Wallace, D. (2006, August 20th). Roger Federer as Religious Experience. New York Times: Play Magazine, p.647.

Hartman, E. (2013). Aristotle on character formation. In C. Luetge (Ed.), Handbook of the philosophical foundations of business ethics (pp. 67-88). Dordrecht: Springer.

Heath, J. (2014). Morality, competition, and the firm: The market failures approach to business ethics. Oxford: Oxford University Press.

Heath, J. (2018). "But Everyone Else Is Doing It": Competition and Business Self-Regulation. Journal of Social Philosophy, 49(4), 516-535.

Heath, J. (2019). Is the "point" of the market Pareto or Kaldor-Hicks efficiency? Business Ethics Journal Review, 7(4), 21-26.

Hsieh, N. H. (2017). The responsibilities and role of business in relation to society: Back to basics? Business Ethics Quarterly, 27(2), 293-314.

Hume, D. (1994). Political essays (K. Haakonssen ed.). Cambridge: Cambridge University Press.

James, C. L. R. (1963). Beyond a Boundary. London: Hutchinson.

Jaworski, P. (2014). An absurd tax on our fellow citizens: The ethics of rent seeking in the market failures (or self-regulation) approach. Journal of Business Ethics, 121(3), 467-476.

Koehn, D. (1997). Business and game-playing: The false analogy. Journal of Business Ethics, 16(12-13), 1447-1452.

MacIntyre, A. (1995). Christianity and Marxism (2nd ed.). London: Duckworth.

MacIntyre, A. (2007). After virtue (3rd ed.). London: Duckworth.

MacIntyre, A. (2016). Ethics in the conflicts of modernity. Cambridge: Cambridge University Press.

Marcoux, A. (2009). Business-focused business ethics. In J. Smith (Ed.), Normative theory and business ethics (pp. 17-34). Lanham, MD: Rowman and Littlefield.

Martin, D. (2013). The contained-rivalry requirement and a 'triple feature' program for business ethics. Journal of Business Ethics, $115(1), 167-182$.

Mathiesen, T. (2005). Prison on trial (3rd ed.). Winchester: Waterside Press.

McMahon, C. (1981). Morality and the invisible hand. Philosophy and Public Affairs, 10(3), 247-277.

McMahon, C. (2013). Public capitalism: The political authority of corporate executives. Philadelphia, PA: University of Pennsylvania Press.

Moore, G. (2012). The virtue of governance, the governance of virtue. Business Ethics Quarterly, 22(2), 293-318. 
Moore, G. (2017). Virtue at work: Ethics for individuals, managers, and organizations. Oxford: Oxford University Press.

Moriarty, J. (2020). On the origin, content, and relevance of the market failures approach. Journal of Business Ethics, 165(1), 113-124.

Morrell, K. (2012). Organization, society and politics: An Aristotelian perspective. London: Palgrave Macmillan.

Mumford, S. (2012). Watching sport: Aesthetics, ethics and emotion. Abingdon: Routledge.

Nielsen, R. P. (2010). High-leverage finance capitalism, the economic crisis, structurally related ethics issues, and potential reforms. Business Ethics Quarterly, 20(2), 299-330.

Néron, P.-Y. (2016). Rethinking the ethics of corporate political activities in a post-Citizens United era: Political equality, corporate citizenship, and market failures. Journal of Business Ethics, 136(4), $715-728$

Nove, A. (2003). The economics of feasible socialism revisited. Abingdon: Routledge.

Nguyen, C. T. (2017). Competition as cooperation. Journal of the Philosophy of Sport, 44(1), 123-137.

Nicholson, H., Beadle, R., \& Slack, R. (2020). Corporate philanthropy as a context for moral agency: A MacIntyrean enquiry. Journal of Business Ethics, 167(3), 589-603.

Norman, W. (2014). Is there 'a point' to markets? A response to Martin. Business Ethics Journal Review, 2(4), 22-28.

Ollman, B. (Ed.). (1998). Market Socialism: The Debate Among Socialists. New York: Routledge.

Pike, J. (2018). Therapeutic use exemptions and the doctrine of double effect. Journal of the Philosophy of Sport, 45(1), 68-82.

Singer, A. (2018). Justice failure: Efficiency and equality in business ethics. Journal of Business Ethics, 149(1), 97-115.

Sinnicks, M. (2014). Practices, governance, and politics: Applying MacIntyre's ethics to business. Business Ethics Quarterly, 24(2), 229-249.

Sinnicks, M. (2019). Moral education at work: On the scope of MacIntyre's concept of a practice. Journal of Business Ethics, 159(1), $105-118$

Sinnicks, M. (2020). The just world fallacy as a challenge to the business-as-community thesis. Business \& Society, 59(6), 1269-1292.

Silver, D. (2016). Competition, value creation and the self-understanding of business. Business Ethics Journal Review, 4(10), 59-65.
Sison, A. J. G. (2008). Corporate governance and ethics: An Aristotelian perspective. Cheltenham: Edward Elgar Publishing.

Sison, A. J. G., \& Fontrodona, J. (2012). The common good of the firm in the Aristotelian-Thomistic tradition. Business Ethics Quarterly, 22(2), 211-246.

Smith, J. (2018). Efficiency and ethically responsible management. Journal of Business Ethics, 150(3), 603-618.

Smith, J. (2019). Navigating our way between market and state. Business Ethics Quarterly, 29(1), 127-141.

Smith, J. (2019). Corporate responsibility and the plurality of market aims. Business and Society Review, 124(2), 183-199.

Solomon, R. C. (1992). Ethics and excellence: Cooperation and integrity in business. New York: Oxford University Press.

Solomon, R. C. (2004). Aristotle, ethics and business organizations. Organization Studies, 25(6), 1021-1043.

Steinberg, E. (2017). The inapplicability of the market-failures approach in a non-ideal world. Business Ethics Journal Review, 5(5), 28-34.

Sternberg, E. (2000). Just business (2nd ed.). Oxford: Oxford University Press.

Vance, A. (2011, April). This Tech Bubble is Different. Bloomberg Businessweek. Retrieved from https://www.bloomberg.com/news/ articles/2011-04-14/this-tech-bubble-is-different.

von Kriegstein, H. (2016). Professionalism, agency, and market failures. Business Ethics Quarterly, 26(4), 445-464.

Whysall, P. (2014). Reflections on ethics, sport and the consequences of professionalisation. Business Ethics: A European Review, 23(4), 416-429.

Wijnberg, N. M. (2000). Normative stakeholder theory and Aristotle: The link between ethics and politics. Journal of Business Ethics, 25(4), 329-342.

Publisher's Note Springer Nature remains neutral with regard to jurisdictional claims in published maps and institutional affiliations. 